\title{
PENERAPAN METODE DISKUSI UNTUK MENINGKATKAN AKTIVITAS DAN HASIL BELAJAR SISWA MATA PELAJARAN IPS KELAS IV POKOK BAHASAN PERKEMBANGAN TEKNOLOGI PRODUKSI, KOMUNIKASI, DAN TRANSPORTASI SDN 25 SANTI KOTA BIMA
}

\author{
Siti Syah Salam \\ SDN 25 Santi Kota Bima \\ Email: sitisyahsalam36222@gmail.com
}

\begin{abstract}
Abstrak. Jenis penelitian yang digunakan dalam penelitian ini adalah penelitian tindakan kelas (PTK). Penelitian ini menggunakan pendekatan kualitatif dan kuantitatif. Pendekatan kualitatif di peroleh dari analis hasil observasi dan wawancara. Sedangkan pendekatan kuantitatif artinya suatu proses menemukan pengetahuan yang menggunakan data berupa angka sebagai alat menentukan keterangan yang ingin diketahui. Adapun subjek penelitian ini adalah siswa kelas IV SDN 25 Santi Kota Bima semester genap tahun ajaran 2015/2016 yang berjumlah 19 orang. Tempat penelitian adalah siswa kelas IV SDN 25 Santi Kota Bima semester genap tahun ajaran 2015/2016. Tujuan dari penelitian ini adalah untuk mengetahui penerapan metode diskusi untuk meningkatkan aktivitas dan hasil belajar siswa mata pelajaran IPS kelas IV pokok bahasan perkembangan teknologi produksi, komunikasi, dan transportasi di SDN 25 Santi Kota Bima. hasil penelitian yang diperoleh adalah sebagai berikut: (1) rata-rata nilai aktivitas belajar siswa siklus I 54,38\% termasuk dalam kategori cukup aktif, sedangkan rata-rata nilai aktivitas belajar siswa siklus II ialah sebesar 78,24\% dan termasuk dalam kategori aktif. (2) kemudian nilai rata-rata hasil belajar siswa pada siklus I sebesar 63,49, jumlah siswa yang tuntas 10 orang, jumlah siswa yang tidak tuntas 9 orang, dan presentase ketuntasan klasikal 52,63\%, dan pada siklus I ini dapat dikategorikan dalam kategori tidak tuntas, sedangkan pada siklus II diperoleh nilai rata-rata 81,58, jumlah siswa yang tuntas 17 orang, jumlah siswa yang tidak tuntas 2 orang, dan presentase ketuntasan klasikal 89,47\%, dan pada siklus II ini dapat dikategorikan dalam kategori tuntas. Kesimpulan penelitian ini ialah penerapan metode diskusi materi pokok Bahasan Perkembangan teknologi produksi, komunikasi dan transportasi dapat meningkatkan aktivitas belajar dan hasil belajar siswa dalam proses pembelajaran IPS di kelas IV SDN 25 Santi Kota Bima.
\end{abstract}

Kata Kunci : Metode Diskusi, Aktivitas Belajar, Hasil Belajar.

\section{PENDAHULUAN}

Ilmu Pengetahuan Sosial (IPS) adalah sebuah mata pelajaran pada jenjang pendidikan dasar dan menengah. Ilmu Pengetahuan Sosial (IPS) yang diberikan di SD adalah ilmu pengetahuan yang mengkaji seperangkat peristiwa, fakta, konsep, dan generalisasi yang berkaitan dengan isu sosial. Pembelajaran IPS bertujuan agar siswa memperoleh pengetahuan, keterampilan, sikap, dan kepekaan untuk menghadapi hidup dengan tantangan-tantangannya. Melalui pembelajaran IPS, siswa diharapkan mampu bertindak secara rasional dalam memecahkan masalah-masalah yang dihadapi (Afandi, 2011:85).
Pemilihan metode pembelajaran yang tepat dalam proses pembelajaran IPS sangat diperlukan agar pembelajaran menjadi efektif, menyenangkan, dan materi tersampaikan dengan baik kepada siswa. Dengan demikian diharapkan aktivitas dan hasil belajar siswa dapat meningkat (Hikmawati, 2013:2). Namun berdasarkan hasil observasi awal, data angket, wawancara, dan dokumentasi yang dilakukan peneliti di SDN 25 Santi Kota Bima diketahui bahwa aktivitas dan hasil belajar masih tergolong rendah. Guru sudah menggunakan beberapa variasi metode pembelajaran namun dirasa masih kurang efektif. , siswa hanya mematuhi perintah guru seperti mencatat, mendengarkan, dan mengerjakan soal sehingga siswa merasa 
jenuh pada saat proses belajar mengajar berlangsung. Salah satu metode yang diterapkan ialah metode dikusi, namun tidak mencerminkan adanya kerja sama yang baik dalam kelompok karena pembelajaran hanya didominasi oleh siswa yang pintar saja, sedangkan siswa yang kurang pintar merasa minder dan mengalami kesulitan dalam menyampaikan gagasan karena kemampuan komunikasi yang masih kurang. Selain itu, penerapan kegiatan diskusi ini tidak sesuai dengan yang diharapkan dalam pembelajaran, karena siswa bukanya memanfaatkan kegiatan tersebut dengan baik, tetapi siswa lebih senang memboroskan waktu dengan bermain dan bercanda. Siswa yang malas hanya menyalin tugas dari temannya yang rajin, sehingga dalam kegiatan siswa tidak aktif dalam mengeluarkan ide atau pendapatnya karena perasaan malu ataupun minder bahwa pendapatnya tidak dapat diterima oleh temantemanya yang lain.

Berdasarkan uraian masalah di atas, dapat dianalisis bahwa faktor-faktor yang menyebabkan rendahnya aktifitas siswa yaitu,metode pembelajaran yang cenderung konvensional, pembentukan kelompok diskusi yang masih sederhana berdasarkan urut absen atau kehendak siswa sendiri, dan kurang optimalnya pemanfaatan buku-buku pembelajaran IPS sebagai sumber belajar siswa.

Pembelajaran konvensional seperti penerapan metode ceramah membuat siswa pasif karena hanya mendengarkan penjelasan dari guru. Pembentukan kelompok diskusi yang dilakukan secara sederhana berdasarkan nomor urut absen atau berdasarkan kehendak siswa sendiri mengakibatkan adanya kelompok yang anggotanya homogen yaitu, ada kelompok yang anggotanya terdiri dari siswa yang pandai, ada juga kelompok yang merupakan siswa kurang pandai, kelompok yang anggotanya hanya siswa perempuan, dan ada kelompok yang anggotanya laki-laki saja. Pemanfaatan buku-buku pembelajaran yang ada juga kurang optimal karena siswa jarang membacanya dan menggunakanya sebagai sumber belajar. Untuk itu dalam pembelajaran diskusi terdapat pembentukan kelompok yang heterogen dimana siswa belajar dan bekerja dalam kelompok-kelompok kecil secara kolaboratif yang beranggotakan 3-5 orang siswa (Setianingsih, 2015:42).

Berdasarkan pengamatan dan pengalaman peneliti selama mengajar mata pelajaran IPS diperoleh bahwa nilai ulangan IPS masih banyak siswa yang memperoleh nilai di bawah Kriteria Ketuntasan Minimal (KKM), masalah belajar yang dihadapai oleh siswa antara lain siswa kurang memiliki kemampuan untuk merumuskan gagasan sendiri, siswa kurang memeiliki keberanian untuk menyampaikan pendapat kepada orang lain, siswa belum terbiasa barsaing menyampaikan pendapat dengan teman lain, kurangnya kerjasama antara sesama teman.

Hasil belajar yang rendah disebabkan proses pembelajaran yang kurang efektif karena kurang membangkitkan keaktifan siswa dalam membentuk sendiri pengetahuanya agar tecipta pemahaman materi yang sedang dipelajari. Agar siswa mencapai hasil belajar yang optimal, guru perlu memperhatikan beberapa faktor yang mempengaruhi belajar siswanya. Faktorfaktor yang mempengaruhi belajar dibedakan menjadi : faktor intern dan ekstern. Faktor intern yang dimiliki siswa meliputi intelegensi, bakat, minat, dan motivasi. Sedangkan faktor ekstern meliputi lingkungan keluarga, sekolah, dan masyarakat (Cahyo : 2013).

Pada penelitian ini metode diskusi merupakan suatu cara yang digunakan untuk meningkatkan aktivitas siswa dalam proses pembelajaran, sehingga tercapai hasil belajar yang optimal dengan prestasi belajar yang bagus melalui beberapa tahapan : 1) pengelompokkan membentuk siswa menjadi 4 kelompok terdiri dari 6 siswa dari setiap kelmpok dengan masing-masing kelompok 1 topik diskusi, 2) siswa merespon permasalahan yang disampaikan oleh guru dalam kelompok diskusi dan merencanakan kerja sama untuk menyelasikan topik padal lembar kerja siswa (LKS) yang dibagikan oleh guru, 3) para siswa berdiskusi pada kelompok masing-masing, 4) setiap siswa mencatat hasil diskusi, 5) tes objektif dan tes 
subjektif. Dengan menggunakan metode ini diharapkan siswa memiliki kemampuan yang baik dalam berkomunikasi da berfikir mandiri maupun dalam keterampilan yang baik dalam berkomunikasi dan berfikir mandiri dalam proses kelompok untuk menciptakan pemahaman dalam diri siswa mengenai materi yang dipelajari, sehingga akan tercapai hasil belajar sesuai yang diharapkan.

Pembelajaran diskusi patut dicoba kembali dan diterapkan sebagai pembelajaran yang lebih inovatif untuk menciptakan pembelajaran yang aktif, kreatif dan menyenangkan. Pada penelitian ini metode diskusi akan dikembangkan dalam pembelajaran IPS dengan pokok bahasan Perkembangan Teknologi Produksi, komunikasi, dan transportasi di kelas IV SDN 25 Santi Kota Bima.

Berdasarkan uraian diatas, maka disusunlah rumusan masalah dalam penelitian ini yaitu: Bagaimanakah penerapan metode diskusi yang dapat meningkatkan aktivitas belajar siswa kelas IV mata pelajaran IPS pokok bahasan Perkembangan teknologi produksi, komunikasi dan transportasi di SDN 25 Santi Kota Bima? dan Bagaimanakah penerapan metode diskusi yang dapat meningkatkan hasil belajar siswa kelas IV mata pelajaran IPS pokok bahasan Perkembangan teknologi produksi, komunikasi dan transportasi di SDN 25 Santi Kota Bima?.

\section{METODE PENELITIAN}

Jenis penelitian yang digunakan dalam penelitian ini adalah penelitian tindakan kelas (PTK). Penelitian tindakan kelas adalah penelitian yang dilakukan oleh guru atau peneliti di dalam kelas, dengan tujuan untuk memperbaiki kinerja guru sehingga hasil belajar siswa meningkat. Metode penelitian tindakan kelas menekankan pada suatu kajian yang benar-benar dari situasi alamiah kelas sehingga mampu memperbaiki dan meningkatkan kualitas belajar mengajar (Arikunto : 2009 : 39).

Penelitian ini menggunakan pendekatan kualitatif dan kuantitatif. Pendekatan kualitatif di peroleh dari analis hasil observasi dan wawancara. Sedangkan pendekatan kuantitatif artinya suatu proses menemukan pengetahuan yang menggunakan data berupa angka sebagai alat menentukan keterangan yang ingin diketahui.

Adapun subjek penelitian ini adalah siswa kelas IV SDN 25 Santi Kota Bima semester genap tahun ajaran 2015/2016 yang berjumlah 19 orang. Tempat penelitian adalah siswa kelas IV SDN 25 Santi Kota Bima semester genap tahun ajaran 2015/2016. Penentuan daerah penelitian ini diterapkan berdasarkan metode Purposive Sampling area.

Prosedur penelitian dilakukan dengan memberikan tindakan pada setiap siklus kegiatan dengan urutan perencanaan, tindakan, observasi, dan refleksi. Kegiatan yang dilakukan pada tahap perencanaan ini adalah sebagai berikut: Meminta izin dari pihak kepala sekolah untuk penelitian di SDN 25 Santi Kota Bima, Wawancara langsung dengan guru bidang studi IPS, Mengumpulkan data mengenai hasil belajar siswa kelas IV yang dapat dilihat melalui ulangan harian kelas, Observasi awal kelas dalam kegiatan belajar mengajar kelas IV, Menentukan pokok bahasan yang akan digunakan untuk penelitian, Pemberian simulasi pada guru bidang studi dan observer mengenai penerapan metode diskusi yang akan dilaksanakan, Membuat kisi-kisi penilaian, Membuat contoh soal, Membuat kunci jawaban

Penelitian ini direncanakan akan dilakukan sebanyak dua siklus. Jika pada siklus I telah tercapai seperti yang diinginkan yaitu tercapainya ketuntasan hasil belajar secara klasikal, maka pelaksanaansiklus II tetap dilakukan dengan sub pokok bahasan selanjutnya. Hal ini dilakukan untuk memantapkan tindakan pada siklus I. Jika hasil yang dicapai belum mencapai yang diinginkan maka dilanjutkan pada siklus II dengan sub pokok bahasan yang sama denga indikator yang berbeda. Tujuan yang ingin dicapai tersebut adalah pencapaian ketuntasan hasil belajar secara klasikal, apabila minimal $85 \%$ yang telah mencapai skor $\geq 70$ dan setiap siswa telah mencapai nilai tes $\geq 70$ atau lebih.

Siklus I dilakukan dalam satu kali pertemuan yaitu dengan alokasi waktu 2 x 35 
menit. Kegiatan belajar mengajar yang dilakukan dalam siklus ini adalah sebagai berikut: Merumuskan masalah secara jelas dengan pimpinan guru para siswa membentuk kelompok-kelompok diskusi memilih pimpinan diskusi (ketua, sekretaris,pelapor), mengatur tempat duduk, ruangan, sarana, dan sebagainya sesuai dengan tujuan diskusi. Melaksanakan diskusi. Setiap anggota diskusi hendaknya tahu persis apa yang akan didiskusikan dan bagaimana cara berdiskusi. Diskusi harus berjalan dalam suasan bebas.Melaporkan hasil diskusinya. Hasilhasil tersebut ditanggapi oleh semua siswa, terutama dari kelompok lain. Guru memberikan alasan atau penjelasan terhadap laporan tersebut. Akhirnya siswa mencatat hasil diskusi, dan guru mengumpulkan laporan hasil diskusi dari setiap kelompok.

Observasi kepada guru dilakukan bersamaan dengan pelaksanaan pembelajaran yang dimaksud untuk mengetahui aktivitas guru dalam penerapan pembelajaran menggunakan metode diskusi. Observasi kepada siswa dilakukan bersamaan dengan tindakan pembelajaran yang bertujuan untuk mengetahui aktivitas siswa selama proses pembelajaran yang meiputi keaktifan siswa dalam memperhatikan pembelajaran, kemampuan bertanya, kemampuan berdiskusi, kemampuan bekerja kelompok, dan kemampuan mengerjakan soal.

Tahap akhir dari siklus 1 adalah tahapan refleksi. Pada tahap refleksi peneliti dan kolaborator dalam hal guru kelas IV mengola nilai yang terdapat pada lembar observasi dan hasil tes yang dan menganalisis kelemahan pada pertemuan pertama dan kedua. Hasil analisis dijadikan sebagai acuan apakah perlu dijadikan perbaikan siklus I pada siklus II atau tidak. Namun apabila siklus I sudah mencapai ketuntasan yang diinginkan yaitu 70 dengan klaskal $85 \%$ maka penelitian ini dilanjutkan pada siklus selanjutnya sebagai pemantapan.

Pelaksanaan siklus II, Pada dasarnya prosedur yang akan dilaksanakan pada siklus II sama dengan siklus I, maka hal-hal yag jadi kekurangan pada siklus I akan di perbaiki dan ditingkatkan agar hasil yang dicapai menjadi optimal.

Metode pengumpulan data dalam penelitian ini untuk memperoleh bahan-bahan yang relevan, akurat, dan dapat digunakan denga cepat sesuai tujuan penelitian. Cara pengambilan data dalam penelitian ini adalah

a. Data hasil belajar diperoleh melalui instrumen penilaian, dalam penelitian ini tes yang digunakan adalah essay (uraian). Tes esseay adalah sejenis tes kemajuan belajar yang memelukan jawaban yang bersifat pembahasan atau uraian kata-kata. Tes dalam penelitian ini bertujuan untuk mengukur kemampuan kognitif siswa.

b. Data tentang situasi belajar mengajar diperoleh dari lembar observasi

c. Data tentang bagaimana respon subjek terhadap kegiatan pembelajaran diperoleh dari pedoman wawancara dengan guru bidang studi yang disesuaikan dengan perkembangan keadaan di lapangan.

Analisa data merupakan cara yang paling menentukan unuk menyusun dan mengolah data yang terkumpul, supaya dapat menghasilkan suatu kesimpulan. Data yang terkumpul dalam penelitian ini dianalisis dengan menggunakan analisis deskriptif, kualitatif, dan kuantitatif untuk menghasilkan data yang dapat dipertanggungjawabkan. Analisis deskriptif di peroleh berdasakan hasil observasi sedangkan analisis kuantitaif dari post tes.

1) Persentase aktivitas siswa

$$
P_{a}=\frac{A}{N_{a}} \times 100 \%
$$

Keterangan :

$\mathrm{Pa}=$ pencapaian keaktifan siswa secara individu

$\mathrm{A}=$ jumlah skor keaktifan siswa yang diperoleh

$N a=$ jumlah skor maksimal keaktifan siswa

2) Hasil belajar siswa dalam pembelajaran IPS mengunakan metode diskusi dengan rumus :

$$
P_{b}=\frac{n}{N_{b}} \times 100 \%
$$

Keterangan : 
$\mathrm{Pb}=$ skor pencapaian hasil belajar siswa secara individu

$n=$ jumlah skor hasil belajar siswa yang diperoleh

$N b=$ jumlah skor maksimal hasil belajar siswa (Tanireja: 2010).

\section{HASIL DAN PEMBAHASAN}

Pelaksanaan penelitian sikus I dilaksanakan mulai dari tanggal 9 Mei 2016 sampai tanggal 16 mei 2016, pelaksanaan siklus I dilakukan sebagai usaha untuk mengatasi masalah yang ditemukan pada saat observasi awal, penerapan metode diskusi diharapkan mampu meningkatkan aktivitas dan hasil belajar siswa mata pelajaran IPS Pokok Bahasan Perkembangan teknologi produksi, komunikasi dan transportasi kelas IV SDN 25 Santi Kota Bima. Kemudian penelitian siklus II dilaksanakan mulai tanggal 23 Mei 2016 sampai tanggal 30 Mei 2016. Pada siklus II ini merupakan kegiatan pemantapan, perbaikan, dan penyempurnaan, dari pelaksanaan siklus I. berdasarkan hasil observasi dan refleksi pada siklus I bahwa hasil ada beberapa siswa yang belum bisa berinteraksi dengan teman satu kelompoknya dan dari hasil tes akhir siklus I diperoleh data bahwa beberapa siswa belum menyelesaikan soal dengan baik. Untuk mengatasi kelemahan-kelamahan pada siklus I, guru perlu mempersiapkan perencanaan yang lebih matang agar hasil yang diperoleh dapat meningkat dari siklus I. Adapun hasil observasi tingkat keaktifan pada setiap siklus diperoleh data :

Tabel 4.1 Tabel hasil observasi aktivitas belajar siswa

\begin{tabular}{|c|c|c|}
\hline Siklus & $\begin{array}{c}\text { Presentase } \\
\text { aktivitas yg } \\
\text { dicapai }\end{array}$ & Kategori \\
\hline Siklus 1 & $54,38 \%$ & Cukup Aktif \\
\hline Siklus II & $78,24 \%$ & Aktif \\
\hline
\end{tabular}

Berdasarkan tabel 4.1 diatas, pada siklus I aktivitas siswa menujukan tingkat aktivitas siswa dengan rata-rata $54,38 \%$, ini termasuk dalam kategori Cukup Aktif, kemudian pada siklus II didapatkan hasil $78,24 \%$, dan ini termasuk kedalam kategori Aktif.

Kemudian data hasil belajar siswa pada setiap siklus tersaji seperti pada tabel berikut:
Tabel 4.2 Tabel hasil observasi hasil belajar siswa

\begin{tabular}{|c|c|c|c|}
\hline \multirow{5}{*}{$\begin{array}{c}\text { Siklus } \\
\text { I }\end{array}$} & Jumlah & 19 & \multirow{5}{*}{$\begin{array}{c}\text { Kategori } \\
\text { Tidak } \\
\text { Tuntas }\end{array}$} \\
\hline & $\begin{array}{l}\text { Nilai Rata- } \\
\text { rata }\end{array}$ & 63,49 & \\
\hline & $\begin{array}{l}\text { Jumlah } \\
\text { siswa yang } \\
\text { tuntas }\end{array}$ & 10 & \\
\hline & $\begin{array}{l}\text { Jumlah } \\
\text { siswa yang } \\
\text { tidak tuntas }\end{array}$ & 9 & \\
\hline & $\begin{array}{l}\text { Presentase } \\
\text { ketuntasan } \\
\text { klasikal }\end{array}$ & $52,63 \%$ & \\
\hline \multirow{5}{*}{$\begin{array}{c}\text { Siklus } \\
\text { II }\end{array}$} & $\begin{array}{l}\text { Jumlah } \\
\text { Siswa (N) }\end{array}$ & 19 & \multirow{5}{*}{$\begin{array}{c}\text { Kategori } \\
\text { Tuntas }\end{array}$} \\
\hline & $\begin{array}{l}\text { Nilai Rata- } \\
\text { rata }\end{array}$ & 81,58 & \\
\hline & $\begin{array}{l}\text { Jumlah } \\
\text { siswa yang } \\
\text { tuntas }\end{array}$ & 17 & \\
\hline & $\begin{array}{l}\text { Jumlah } \\
\text { siswa yang } \\
\text { tidak tuntas }\end{array}$ & 2 & \\
\hline & $\begin{array}{l}\text { Presentase } \\
\text { ketuntasan } \\
\text { klasikal }\end{array}$ & 89,47 & \\
\hline
\end{tabular}

Berdasarkan tabel 4.2 diatas, dapat dilihat bahwa pada siklus I dengan jumlah siswa 19 orang, nilai rata-rata 63,49, jumlah siswa yang tuntas 10 orang, jumlah siswa yang tidak tuntas 9 orang, dan presentase ketuntasan klasikal 52,63\%, dan pada siklus I ini dapat dikategorikan dalam kategori tidak tuntas sebab belum memenuhi presentase ketuntasan klasikal. Kemudian pada siklus II diperoleh nilai rata-rata 81,58 , jumlah siswa yang tuntas 17 orang, jumlah siswa yang tidak tuntas 2 orang, dan presentase ketuntasan klasikal 89,47\%, dan pada siklus II ini dapat dikategorikan dalam kategori tuntas sebab memenuhi standar ketuntasan klasikal yakni $\geq 85 \%$.

Berdasarkan dari hasil observasi aktivitas belajar siswa pada siklus I yang dilakukan selama proses pembelajaran yag diketahui perolehan skor rata-rata $54,38 \%$. Hasil observasi pada siklus I masih ada beberapa siswa masih cenderung malu-malu 
saat presentasi dan siswa cenderung masih malu untuk mengutarakan pendapatnya sehingga masih kurang memperhatikan penjelasan guru saat diskusi kelompok siswa masih kurang disiplin. Beberapa siswa ada yang hanya mengutak-atik buku tidak mau berkerjasama dengan teman kelompoknya dan hanya ikut-ikutan tidak mau membantu untuk mencari jawaban. Pada siklus II diketahui perolehan skor rata-rata 78,24\% pembelajaran lebih tertib, hal ini nampak pada saat siswa mengikuti proses belajar mengajar siswa lebih aktif dalam diskusi kelompok maupun memecahkan masalah. Kemudian semua perintah guru langsug dilakukan siswa dengan baik dan benar.

Kendala yang dihadapai siswa dalam penerapan metode diskus pada siklus I ini adalah masih malu untuk bertanya, siswa cenderung masih malu untuk mengutarakan pendapatnya sehingga masih kurang komunikatif karena metode diskusi dengan langkah-langkah yang telah ditentukan baru diterapkan di kelas IV.

Langkah-langkah yang diambil untuk mengatasi kondisi siklus I untuk langkah perbaikan pada siklus II yaitu guru harus membuat kesepekatan terlebih dahulu dan memberi sanksi bagi siswa yang melanggar, agar siswa belajar untuk disiplin dan bertanggung jawab lembar kerja siswa sebaiknya berisi permasalahan yang dapat mengembangkan nalar siswa, selain itu guru lebih memberikan bimbingan dan arahan pada saat presentasi agar siswa lebih komunikatif tidak malu lagi untuk mengungkapkan pendapatnya sehingga suasana menjadi lebih hidup. Kemudian penggunaan waktu yang digunakan guru juga harus diperhitungkan sesuai dengan rencana pembelajaran.

Berdasarkan dari hasil observasi pada siklus II yang dilakukan selama proses pembelajaran diketahui bahwa tingkat belajar siswa mengalami peningkatan bila dibandingkan siklus I, yaitu secara klasikal $52,63 \%$ menjadi $89,47 \%$. Suasana kelas pada siklus II ini tampak lebih tertib, sehingga pembelajaran berjalan dengan lancar. Pada saat diskusi seluruh siswa lebih aktif dan memecahka soal di masing-masing kelompok
, guru juga lebih mampu memperhatikan dan lebih tanggap terhadap setiap kegiatan yang dilakukan siswa dalam proses pembelajaran. Dalam pembelajaran metode diskusi pada mata pelajaran IPS pada siklus II hanya mendapat kriteria aktif.

Hasil wawancara dengan siswa menunjukan bahwa siswa senang dan antusias dengan diterapkan metode diskusi karena siswa mampu untuk meningkatkan rasa tanggung jawab siswa terhadap pembelajarannya sendiri dan juga pembelajaran orang lain, penerimaan terhadap perbedaan individu lebih besar, pemahaman materi lebih mendalam, serta meningkatkan motivasi belajar.

Dalam pembelajaran IPS yang menerapkan metode diskusi guru merasa senang. Karena dalam pembelajaran IPS siswa menjadi aktif, siswa mencatat yang penting-penting saat guru menjelaskan. Keaktivan siswa juga dapat dilihat pada saat berdiskusi. Semua siswa mempelajari dan memahami materi dengan baik. Karena masing-masing siswa memiliki tanggung jawab untuk menjelaskan materi pada temanya. Guru yang merasa senang saat menerapkan metode diskusi juga diikuti rasa senangnya siswa didalam pembelajaran. Siswa mengungkapkan bahwa aktivitas dan hasl belajarnya meningkat, yang sebelumnya hanya diam mendengarkan sudah berubah menjadi aktif memahami materi dan menjelaskan pada temannya. Hasil belajar siswa yang semula dibawah KKM yang ditentukan.

\section{KESIMPULAN}

Berdasarkan hasil penelitian dan pembahasannya dapat diambil kesimpulan bahwa penerapan metode diskusi materi pokok Bahasan Perkembangan teknologi produksi, komunikasi dan transportasi dapat meningkatkan aktivitas belajar siswa dalam proses pembelajaran IPS di kelas IV SDN 25 Santi Kota Bima hal ini dapat dibuktikan dari aktivitas belajar siswa yang meningkat selama pelaksanaan tindakan pada masing-masing siklus. Presentase keaktifan secara klasikal pada siklus I adalah $54,38 \%$ dan presentase keaktifan pada siklus II adalah 78,24\% dan Pembelajaran dengan menggunakan metode 
diskusi dapat meningkat hasil belajar siswa dalam pembelajaran IPS materi Pokok Bahasan Perkembangan teknologi produksi, komunikasi dan transportasi pada siswa kelas IV SDN 25 Santi Kota Bima Juga mengalami penigkatan ketuntasan hasil belajar siswa secara klasikal pada siklus I sebesar 52,63\%, siswa yang tuntas belajar secara individu sebanyak 10 siswa dan yang tidak tuntas secara individu sebanyak 9 siswa, sedangkan siklus II terjadi peningkatan ketuntasan hasil belajar secara klasikal mencapai 89,47\%, siswa yang tuntas belajar secara individu sebanyak 17 Siswa dan yang tifak tuntas sebanyak 2 siswa.

\section{SARAN}

1. Bagi guru, pembelajaran IPS dengan menggunakan metode diskusi dapat dijadikan sebagai salah satu alternative bagi guru untuk menggunakannya dalam pembelajaran IPS pada khususnya. Karena dapat membuat siswa tertarik, merasa senang, melatih rasa tanggung jawab siswa, dan rasa sosialisai siswa.

2. Bagi siswa, berdasarkan temuan penelitian dan pembahasan, bagi siswa yang belum tuntas dan kurang memahami materi Perkembangan teknologi produksi, komunikasi dan transportasi perlu diberi bimbingan secara individu agar siswa lebih mampu untuk memahami materi selanjutnya. Siswa selalu diberi motivasi salah satunya diberi pujian setiap mereka melakukan hal yang benar sehingga siswa tumbu percaya diri.

3. Bagi sekolah, hasil penelitian ini dapat digunakan sebagai bahan masukan tentang salah satu alternatif cara pengajaran atau pembelajaran IPS dengan menerapkan metode diskusi.

4. Bagi peneliti lain, penelitian ini dapat dijadikan sebagai masukan bagi peneliti lain untuk melakukan penelitian dengan pokok bahasan berbeda.

\section{DAFTAR PUSTAKA}

Afandi, R. 2011. Integrasi pendidikan karakter dalam pembelajaran IPS di sekolah dasar. Jurnal Pedagogia. Vol.1(1) : 85-98.
Arikunto, S., 2002. Dasar-Dasar Evaluasi Pendidikan. Jakarta: Bina Askara.

Arikunto, S., 2009. Prosedur Penelitian Suatu Pendekatan Praktik. Edisi Revisi 6. Jakarta: Rineka Cipta.

Cahyo, Agus (2013). Panduan Aplikasi TeoriTeori Belajar Mengajar Teraktual dan terpopuler. Diva Press. Jogyakarta.

Hikmawati, C. R. 2013. Penerapan Strategi mind Map untuk meningkatkan hasil belajar IPS siswa kelas V sekolah dasar. Jurnal PGSD. Vol. 1 (2) : 2.

Muhibbin, Syah. 2000. Psikologi Pendidikan Dengan Pendekatan Baru.Bandung: Remaja Rosda Karya.

Setianingsih, D. A. Ramadhan, dan Y. Gagaramusu. 2015. Meningkatkan Pemahaman Konsep Bagian-bagian Tumbuhan melalui Pembelajaran Kooperatif Model STAD pada Siswa kelas IV SDN 02 Laantula Jaya Kec. Wita Ponda Kab. Morowali. Jurnal Kreatif Tadulako. Vol. 3 (2) : 41.

Supria, dkk. 2009. Konsep Belajar Dan Pembelajaran. Bandung: Remaja Rosda Karya Offset.

Tanireja, Pujiati, Nyata. 2010. Penilaian Tindakan Kelas. Bandung: CV Alfabeta. 